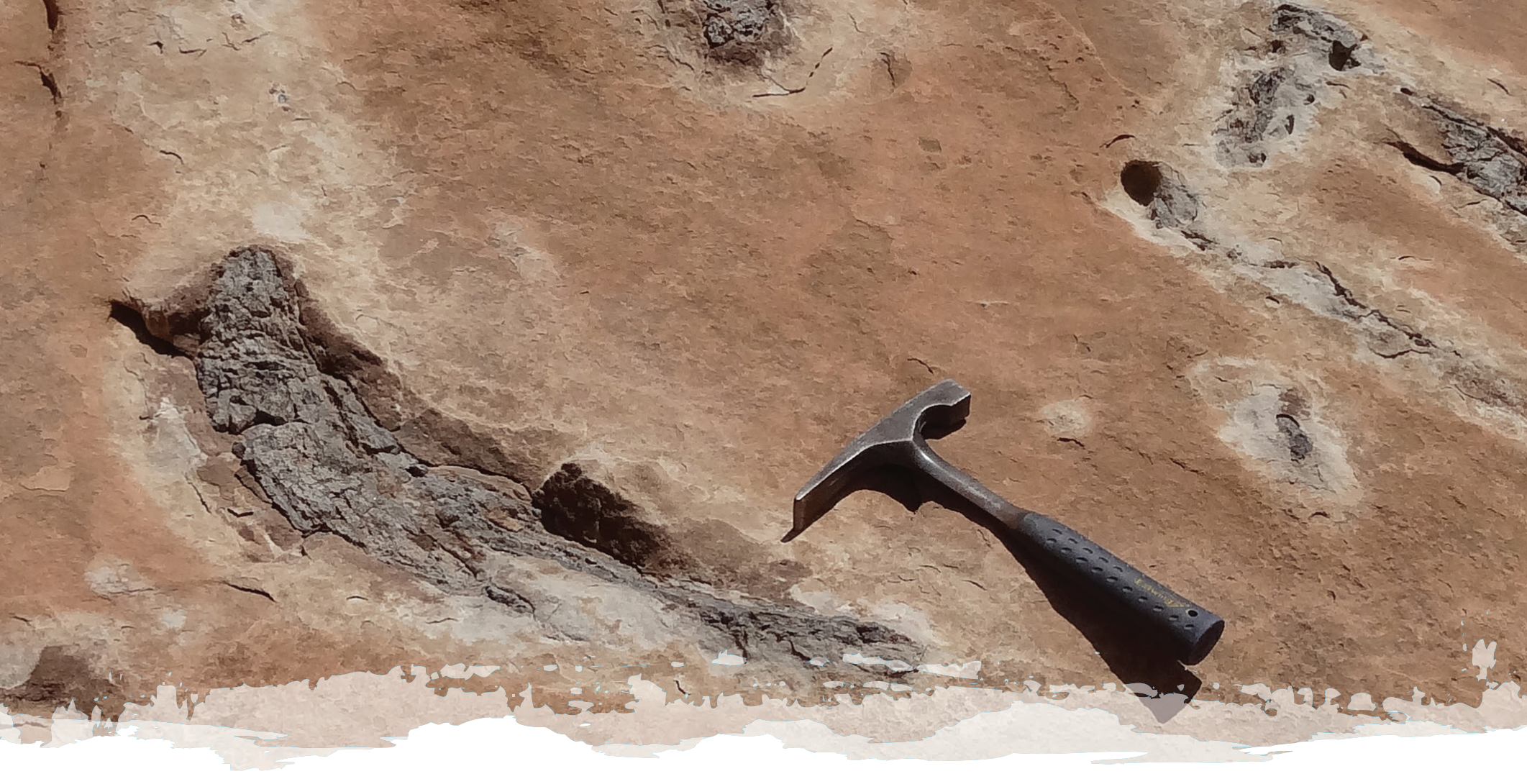

\title{
Plant Root Systems Preserved in the Permian Cedar Mesa Sandstone at Moki Dugway, Southeastern Utah
}

David B. Loope

Earth \& Atmospheric Sciences, University of Nebraska

Lincoln, NE 68588-0340

dloope1@unl.edu

\section{Utah Geosites \\ 2019}

Utah Geological Association Publication 48

M. Milligan, R.F. Biek, P. Inkenbrandt, and P. Nielsen, editors

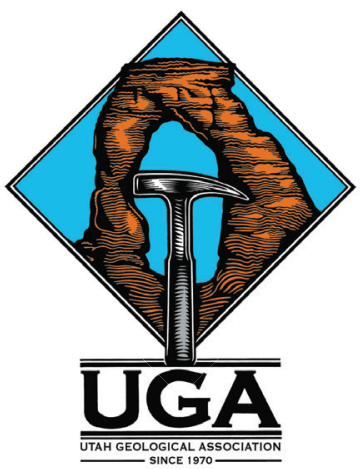




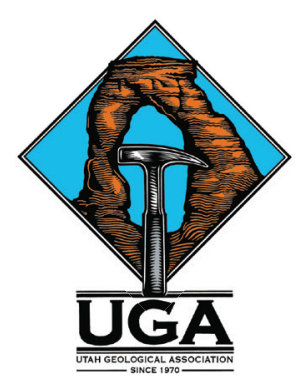

\section{Utah Geosites} 2019

\section{Utah Geological Association Publication 48}

M. Milligan, R.F. Biek, P. Inkenbrandt, and P. Nielsen, editors

Utah Geosites showcases some of Utah's spectacular geology, both little-known localities and sites seen by visitors to Utah's many national and state parks and monuments. The geosites reflect the interests of the many volunteers who wrote to share some of their favorite geologic sites. The list is eclectic and far from complete, and we hope that additional geosites will be added in the coming years. The Utah Geological Survey also maintains a list of geosites https://geology.utah.gov/apps/geosights/index.htm.

We thank the many authors for their geosite contributions, Utah Geological Association members who make annual UGA publications possible, and the American Association of Petroleum Geologists-Rocky Mountain Section Foundation for a generous grant for desktop publishing of these geosite papers.

Design and desktop publishing by Jenny Erickson, Graphic Designer, dutchiedesign.com, Salt Lake City, Utah.

This is an open-access article in which the Utah Geological Association permits unrestricted use, distribution, and reproduction of text and figures that are not noted as copyrighted, provided the original author and source are credited. See the Utah Geological Association website, www.utahgeology.org, and Creative Commons https://creativecommons.org/licenses/by/4.0/ for details.

Suggested citation for this geosite:

Loope, D.B., 2019, Plant root systems preserved in the Permian Cedar Mesa Sandstone at Moki Dugway, southeastern Utah, in Milligan, M., Biek, R.F., Inkenbrandt, P., and Nielsen, P., editors, Utah Geosites: Utah Geological Association Publication 48, 6 p., https://doi.org/10.31711/geosites.v1i1.60.

\section{Presidents Message}

I have had the pleasure of working with many different geologists from all around the world. As I have traveled around Utah for work and pleasure, many times I have observed vehicles parked alongside the road with many people climbing around an outcrop or walking up a trail in a canyon. Whether these people are from Utah or from another state or country, they all are quick to mention to me how wonderful our geology is here in Utah.

Utah is at the junction of several different geological provinces. We have the Basin and Range to the west and the Central Utah Hingeline and Thrust Belt down the middle. The Uinta Mountains have outcrops of some of the oldest sedimentary rock in Utah. Utah also has its share of young cinder cones and basaltic lava flows, and ancient laccoliths, stratovolcanoes, and plutonic rocks. The general public comes to Utah to experience our wonderful scenic geology throughout our state and national parks. Driving between our national and state parks is a breathtaking experience.

The "Utah Geosites" has been a great undertaking by many people. I wanted to involve as many people as we could in preparing this guidebook. We have had great response from authors that visit or work here in the state. Several authors have more than one site that they consider unique and want to share with the rest of us. I wanted to make the guidebook usable by geologists wanting to see outcrops and to the informed general public. The articles are well written and the editorial work on this guidebook has been top quality.

I would like to personally thank Mark Milligan, Bob Biek, and Paul Inkenbrandt for their editorial work on this guidebook. This guidebook could not have happened without their support. I would like to thank Jenny Erickson for doing the great desktop publishing and the many authors and reviewers that helped prepare the articles. Your work has been outstanding and will certainly showcase the many great places and geology of Utah. Last, but not least, Thank you to the American Association of Petroleum Geologists, Rocky Mountain Section Foundation for their financial support for this publication.

Guidebook 48 will hopefully be a dynamic document with the potential to add additional "geosites" in the future. I hope more authors will volunteer articles on their favorite sites. I would like to fill the map with locations so that a person or family looking at the map or articles will see a great location to read about and visit. Enjoy Guidebook 48 and enjoy the geology of Utah.

Peter J. Nielsen

2019 UGA President 


\section{INTRODUCTION}

Rooted green plants represent the base of the food chain for most terrestrial ecosystems, but, compared to animal burrows, root systems are relatively rarely recognized in ancient sedimentary rocks. Plant roots that penetrate unconsolidated sand dunes, especially those containing not only quartz grains, but also abundant grains of calcite $\left(\mathrm{CaCO}_{3}\right)$, are commonly replaced by fine crystals of calcite (Klappa, 1980). These structures (known by geologists as rhizoliths from the Greek for "root rock") are one form of calcite cemented soil and sediment called caliche (figure 1). Caliche crystallizes well above the water table and its calcite crystals are tiny because of rapid evaporation of soil water. One source of the calcium $(\mathrm{Ca})$ and carbonate $\left(\mathrm{CO}_{3}\right)$ ions necessary for making the calcite of caliche is falling dust, and another source is the dissolution of calcite grains already in the soil.

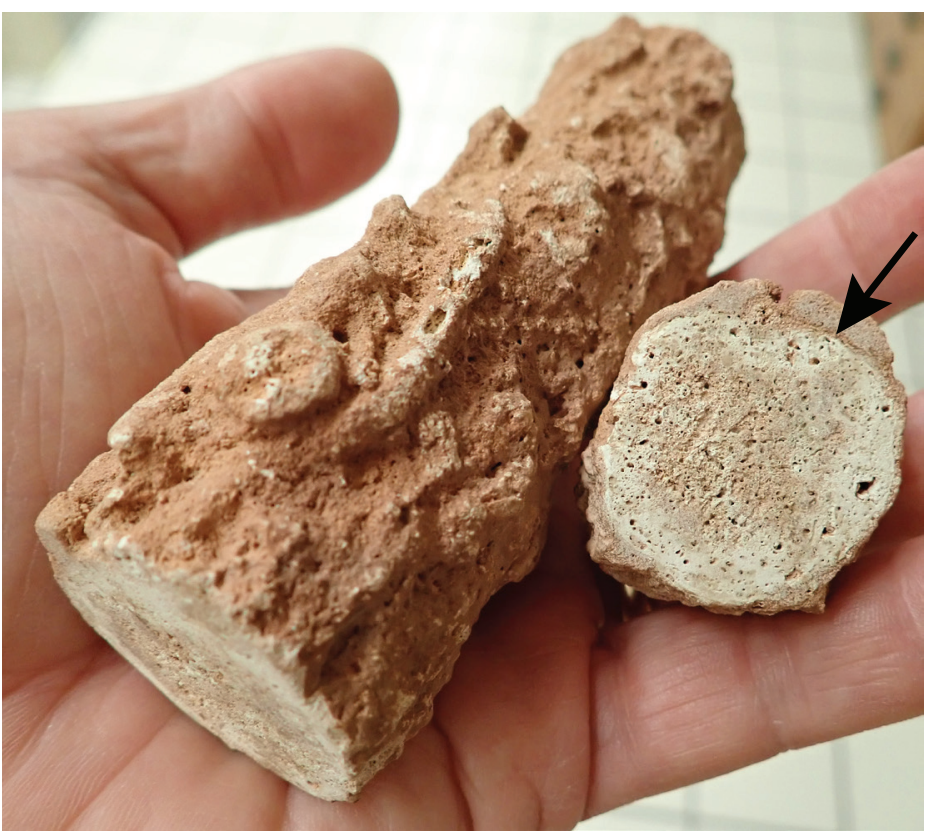

Figure 1. Rhizolith collected from loose, bioturbated dune sand north of Moab, UT. Arrow points to the boundary between lightly cemented quartz sand and sand-free caliche composed tiny calcite crystals. Void spaces were made by smaller roots that penetrated the soft, chalky caliche that fills the cylindrical space produced by growth of a large root.

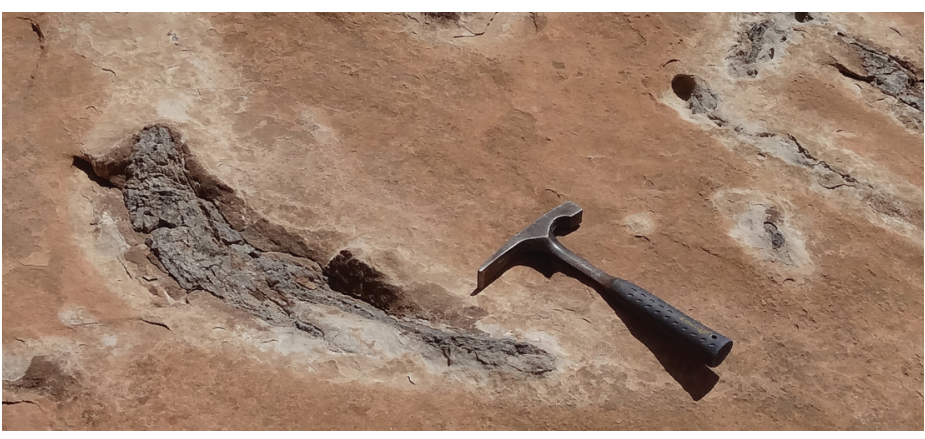

Figure 2. Permian rhizoliths in the Cedar Mesa Sandstone at Moki Dugway. These rhizoliths have a darker color than those found in recently deposited, uncemented sand (figure 1) because all the pore space originally in them has been filled by calcite cement. The lighter patches of sandstone are reduction halos-iron oxide was removed from surrounding quartz grains by organic acid from the root.
Caliche is widespread in semi-arid regions. In regions with abundant rainfall, available calcium and carbonate ions are rapidly flushed downward, out of the soil, preventing calcite crystals from growing in the root zone. In arid regions there is too little available soil water for crystal growth.

Because plant roots in modern semi-arid settings are commonly preserved by caliche (figure 1), rhizoliths in ancient rocks are good indicators of semi-arid paleoclimates. The Early Permian (245-286 million year old) root systems preserved the Cedar Mesa Sandstone at Moki Dugway (figure 2) grew on low-relief land surfaces that formed when dune fields were flattened by wind erosion. A near-surface water table may have prevented further erosion of the Permian dune sand and allowed the land surface to be colonized by woody plants.

\section{DRIVING AND WALKING DIRECTIONS}

Perhaps the best place in the U.S. to see ancient rhizoliths is in a Utah 261 roadcut along the upper portion of Moki Dugway and on the outcrop just above the highest switchback (figure 3). If you are approaching this geosite from the north, stop first at the viewpoint on the south edge of Cedar Mesa, at the top of Moki Dugway (figure 3 ). This viewpoint provides a dramatic view of the Cedar Mesa Sandstone, and in the distance, the Goosenecks of the San Juan River and Monument Valley (figure 4). The Moki Dugway is a steep (11\% grade), well-maintained, dirt road with

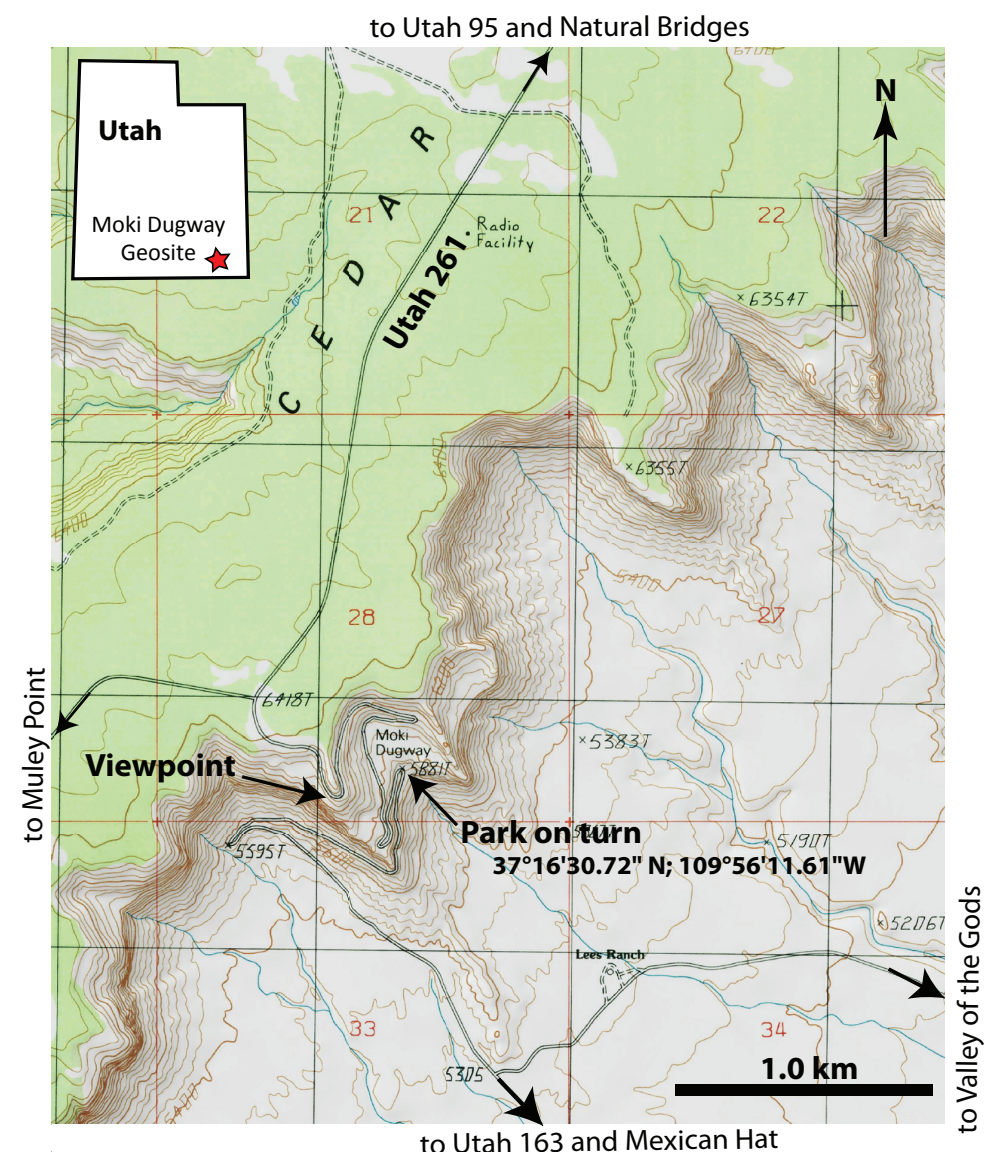

Figure 3. Topographic map showing the roads that provide access to this geosite and the recommended stopping places. 


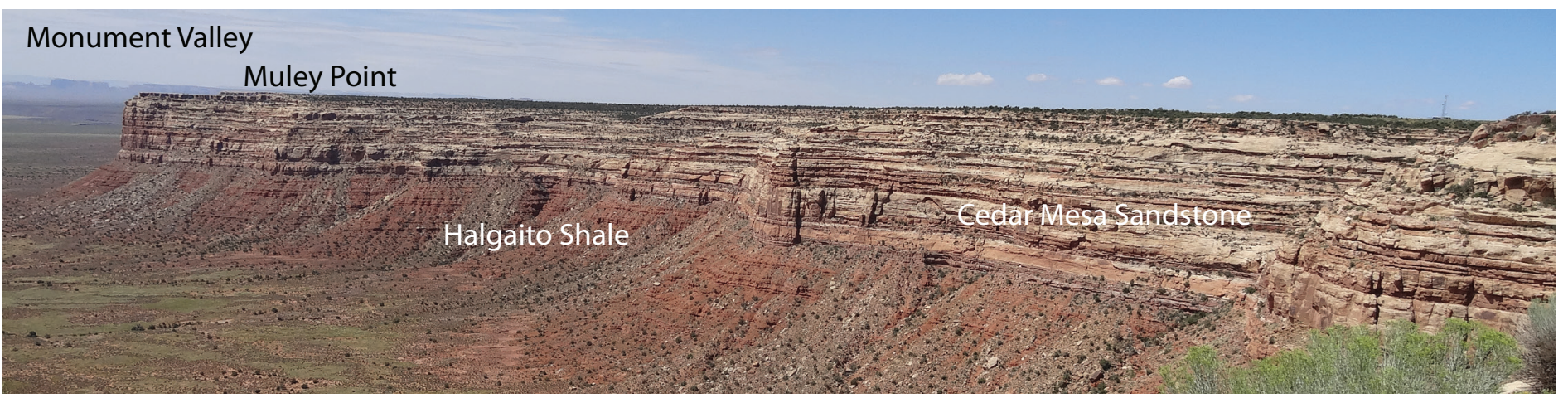

Figure 4. View southward from the parking area at the top of Moki Dugway.

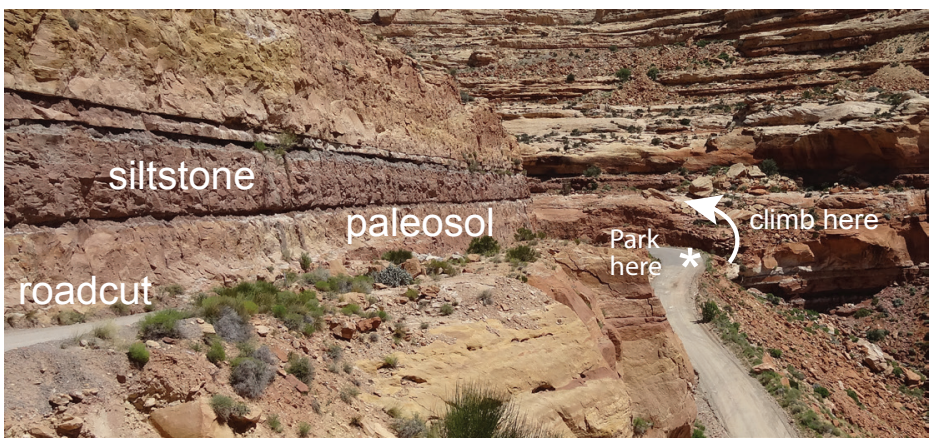

Figure 5. Cedar Mesa Sandstone outcrops along upper part of Moki Dugway where the rhizoliths in one of the Permian paleosols are best exposed.

a series of switchbacks. Unless it is wet, neither high-clearance nor $4 \mathrm{WD}$ are needed. The State of Utah recommends it only for vehicles less than 28 feet long and less than 10,000 pounds. For viewing the rhizoliths up close, the best place to park is at the uppermost sharp switchback on the highly sinuous road (figure 3). It is possible to climb up the outcrop at the outer bend of this switchback; you can also see rhizoliths exposed along both sides of the roadcut as you walk back up the road a few hundred meters. If you approach this geosite from the south, use figures 3 and 5 to help you recognize the correct switchback for parking.

\section{GPS Location: N37.2752; W109.9365 (WGS84)}

\section{THE CEDAR MESA SANDSTONE}

The Permian Cedar Mesa Sandstone is one of more than a dozen thick sedimentary rock formations on the Colorado Plateau that were deposited by large, wind-blown sand dunes (figure 5). All of these sandstones have large-scale crossbedding that formed as the dunes migrated downwind and accumulated vertically in subsiding sedimentary basins. Because Mesozoic rock formations have been eroded from the broad crest of the Monument Uplift (figure 6) in southeastern Utah (named for Monument Valley) older rocks including the Cedar Mesa Sandstone crop out widely there, forming Cedar Mesa (type locality of the formation), as well as The Needles and The Maze (Canyonlands National Park), and the natural bridges at Natural Bridges National Monument.

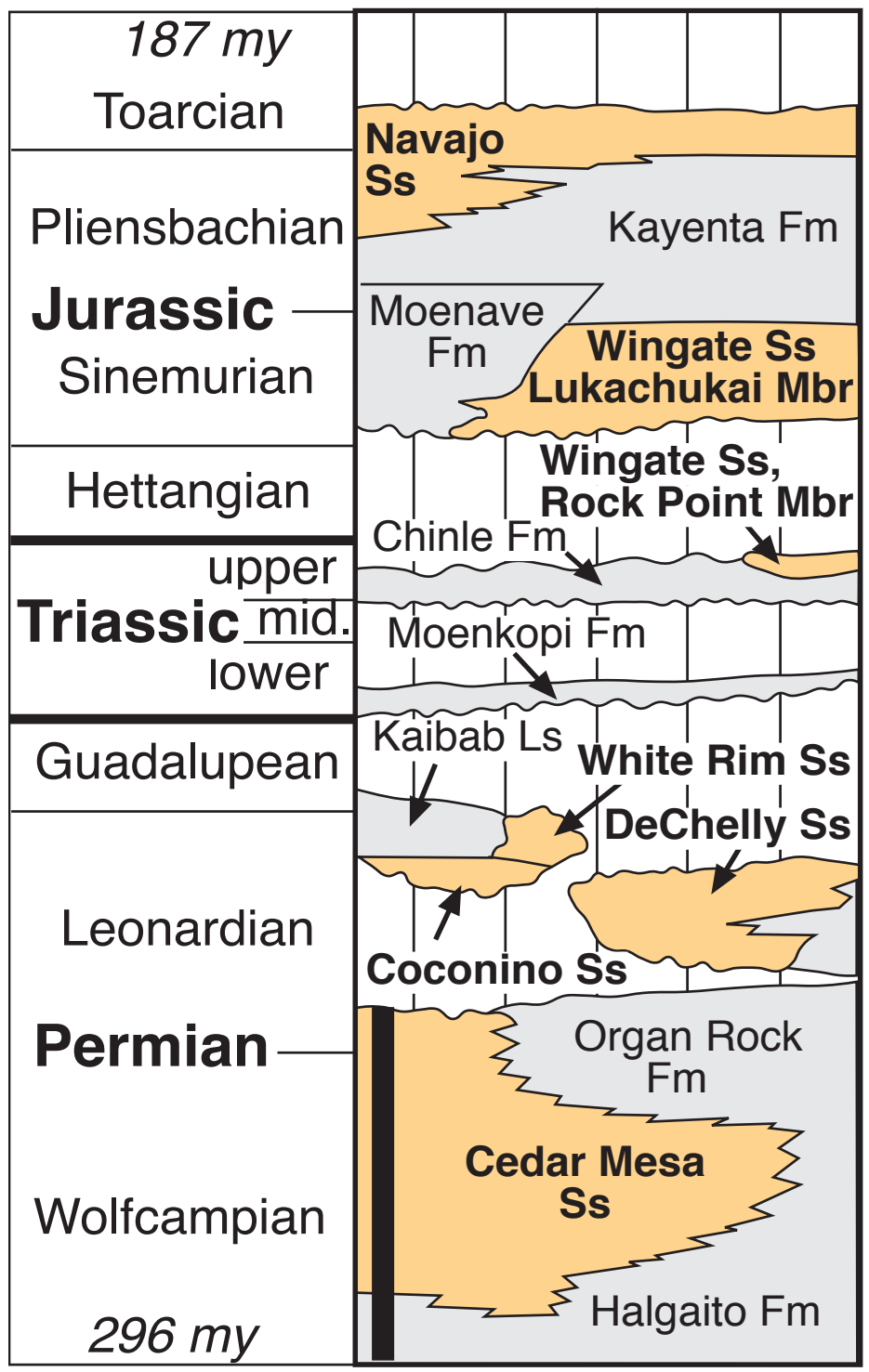

Figure 6. Eolian sandstones of the Colorado Plateau (orange). Vertical scale is geologic time. The black bar shows the strata that crop out at Moki Dugway. Modified from Blakey and others (1988).

Most of the sand grains that accumulated to form the Cedar Mesa Sandstone are abraded crystals of quartz and feldspar (ultimately derived from granite or gneiss). But calcite (calcium carbonate) grains are also present, and some of these can (using a microscope) be recognized as fragments of the skeletons of marine invertebrates-brachiopods, bryozoans, and crinoids. These animals 


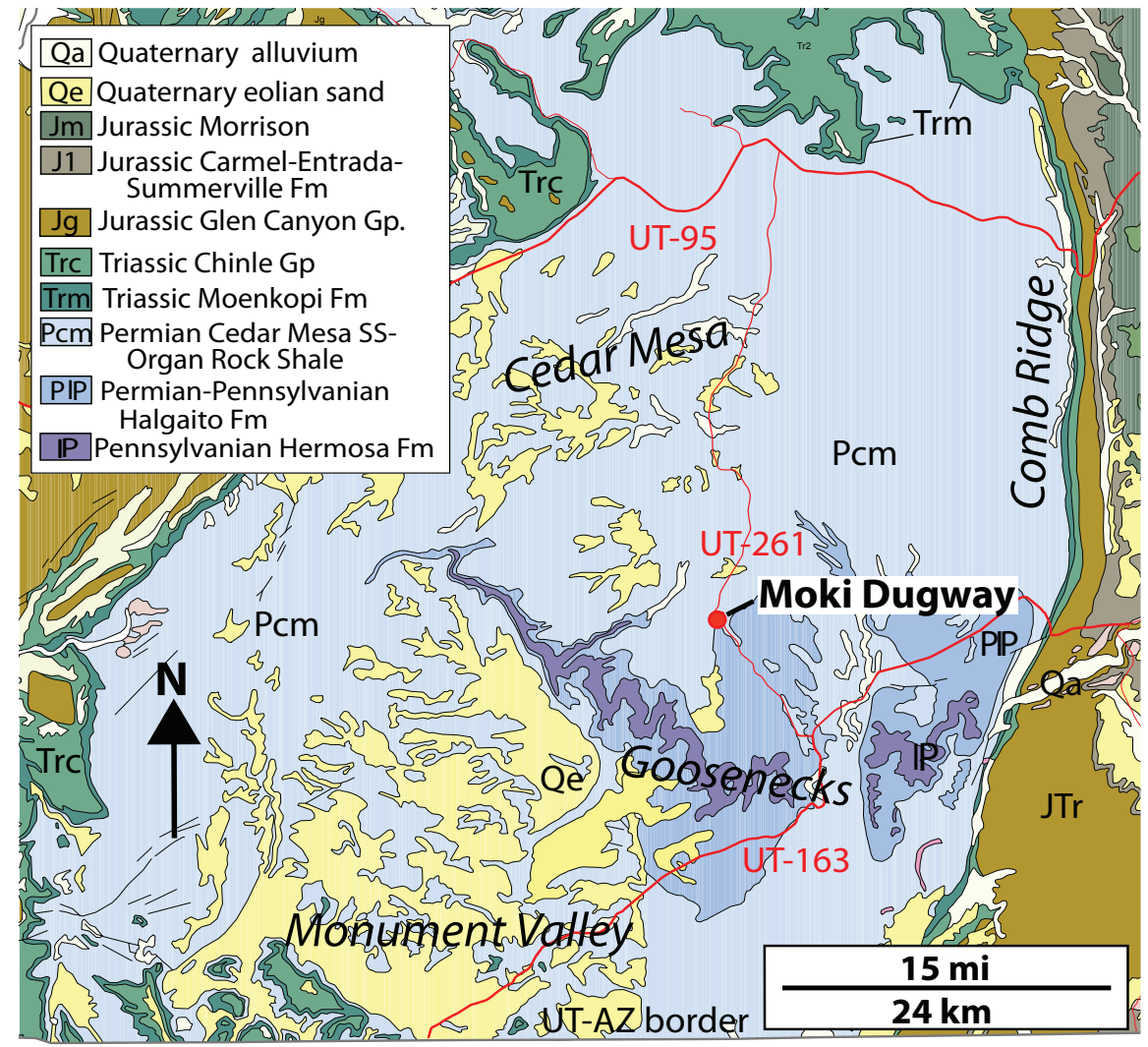

Figure 7. Geologic map of the area surrounding Moki Dugway (left). The older rocks (blue and purple) are exposed because of erosion of younger rocks (tan and green) from the Monument Uplift. The column on the right shows strata exposed in the area. The black bar shows the strata that crop out at Moki Dugway. Map based on Interactive Geologic Map of Utah (Utah Geological Survey); column based on Hintze and Kowallis (2009).

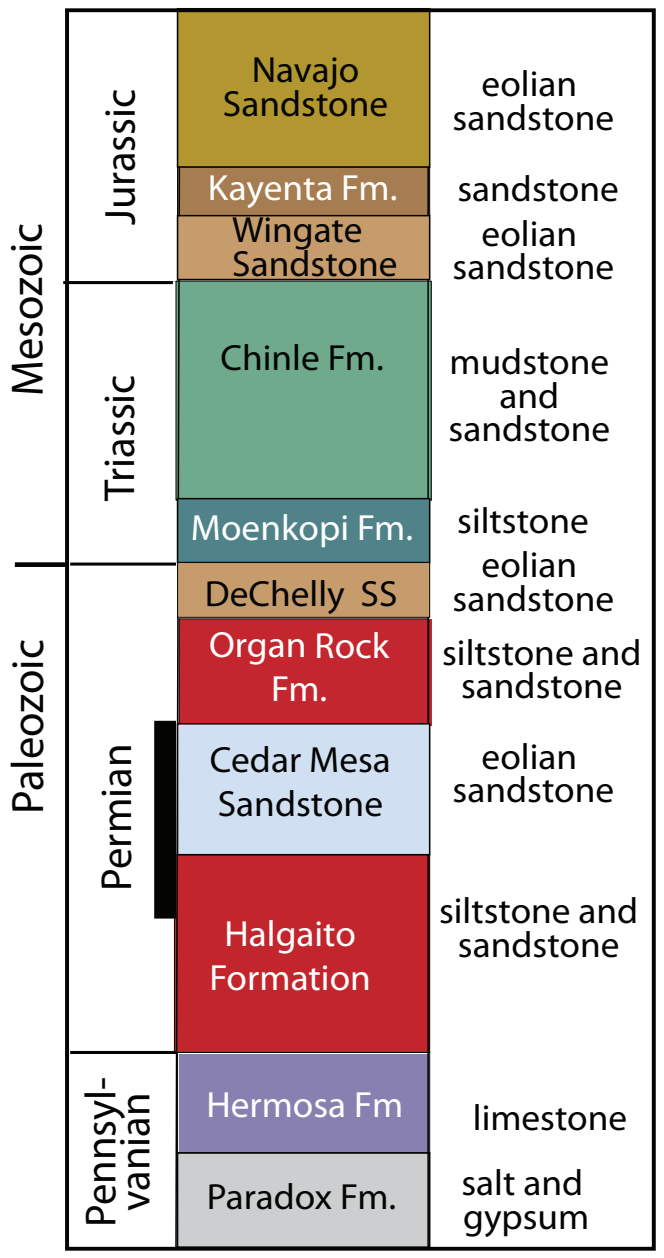

lived in a shallow seaway that lay to the north and west, and were incorporated into a broad coastal dune field by onshore winds. After the dunes were eroded flat (see below), the presence of these calcite grains in the dune sand became important to the excellent preservation of root systems in the Cedar Mesa Sandstone.

\section{STACKING OF SEDIMENT SLABS AND PRESERVATION OF ROOT SYSTEMS}

Although some of the eolian sandstones of the Colorado Plateau form massive, uninterrupted cliffs (for example, the Jurassic Navajo and Wingate Sandstones, figures 6 and 7), the cliffs exposing the Cedar Mesa Sandstone are discontinuous, giving the Cedar Mesa a tabular, "layer-cake" appearance caused by alternation of thin, red siltstones with up to 40 distinct 6 to 65 feet thick ( 2 to 20 meters) slabs of sandstone (figures 4, 5, 8; Loope, 1985; Mountney, 2006). During the Permian Period, massive glaciers were dynamically forming and melting on the supercontinent Gondwana. Clearly, global climate was fluctuating widely. When sand was abundant and winds were relatively gentle, sand built up as dunes climbed over one another. Onshore winds led to the incorporation of calcite grains (fragments of marine fossils) into the desert dunes (Loope, 1984). But as the wind strengthened (or the supply of sand to the dune field diminished), the dunes were eroded and silt (probably delivered as dust fall and from small streams) started to accumulate on flat surfaces. Abundant rhizoliths provide evidence that these flat surfaces were colonized by terrestrial plants. Because vegetation slows the wind, the plants likely caused the falling silt to accumulate instead of continuing its downwind migration.

The rock layers with rhizoliths are thus paleosols (ancient soils) preserved in the stratigraphic record. The diameters of the rhizoliths (figure 2) indicate that many of the plants were medium to large trees. The roots of trees and the burrows of small invertebrates (probably insects) penetrated the uncemented sand, obliterating the bedding in the upper portions of each tabular accumulation. Beyond the reach of the roots and burrows, undisturbed crossbedding was preserved in the lower portions of each tabular sand accumulation.

Crustaceans such as shrimp and crayfish build complex, branching burrow systems, but, unlike root systems, the burrows are filled by loose sand (never by sand-free, fine-grained calcite). The rod-like form and coloration of the Cedar Mesa structures are produced by: 1) elongation and radial expansion of a cylindrical plant root that pushed sand grains aside; 2) a living root and its rootlets that 


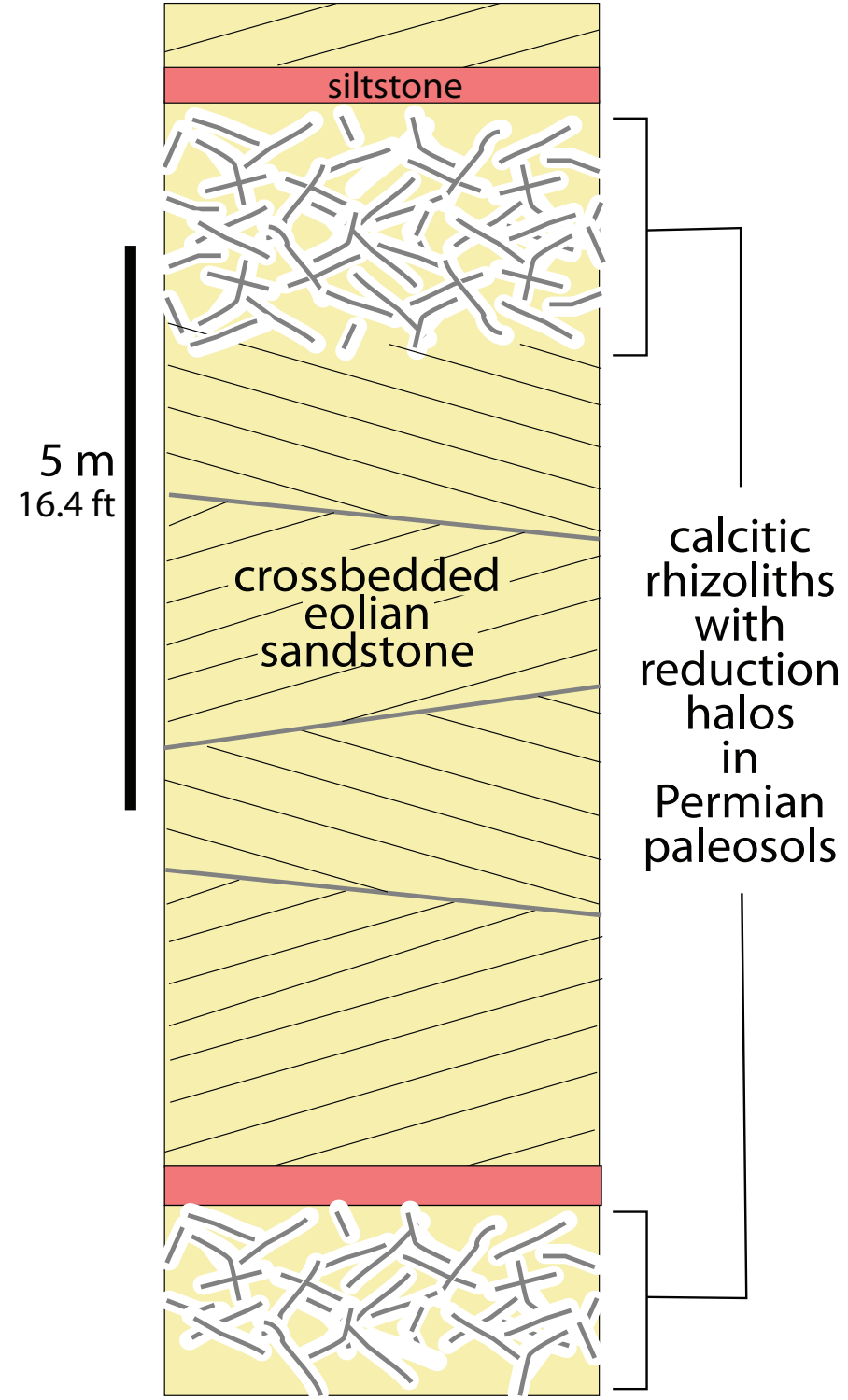

Figure 8. Relationships of thin siltstones and rhizolith-bearing paleosols to tabular sheets of crossbedded sandstone in the Permian Cedar Mesa Sandstone.

produced acid that dissolved iron oxide from the surrounding sediment, producing a "reduction halo" (figures 2 and 8). Much of the dead organic tissue is eventually replaced by fine-grained calcite (figures 1 and 2; Loope, 1988).

A sandstone like the Cedar Mesa, with abundant sand-size, marine fossils could have been interpreted as forming below sea level. And the obliteration of bedding (called "bioturbation" by many geologists) could have been interpreted as evidence for burrowing by marine invertebrates such as crustaceans. But the distinctive, large-scale crossbedding shows that onshore winds blew the marine fossils (along with abundant quartz and feldsper) onto an emergent land surface covered by sand dunes, and the sandfree calcite rods representing ancient caliche show that the desert dunes were periodically flattened and colonized by land plants growing in a semi-arid climate.

\section{ACKNOWLEDGMENTS}

Nigel Mountney, Jon Mason, and Jodi Norris provided very helpful reviews of this paper.

\section{REFERENCES}

Blakey, R.C., Peterson, F., and Kocurek, G., 1988, Synthesis of late Paleozoic and Mesozoic eolian deposits of the Western Interior of the United States: Sedimentary Geology, v. 56, p. 3-125.

Hintze, L.F., and Kowallis, B.J., 2009, Geologic History of Utah: Brigham Young University Geology Studies, Special Publication $9,225 \mathrm{p}$.

Klappa, C.F., 1980, Rhizoliths in terrestrial carbonates: classification, recognition, genesis and significance: Sedimentology, v.27, p. 613-629.

Loope, D.B, 1984, Eolian origin of upper Paleozoic sandstones, southeastern Utah: Journal of Sedimentary Research, v. 54, p. 563-580.

Loope, D.B., 1985, Episodic deposition and preservation of eolian sands: A late Paleozoic example from southeastern Utah: Geology, v. 13, p. 73-76.

Loope, D.B., 1988, Rhizoliths in ancient eolianites: Sedimentary Geology, v. 56, p. 301-314.

Mountney, N.P., 2006, Periodic accumulation and destruction of aeolian erg sequences in the Permian Cedar Mesa Sandstone, White Canyon, southern Utah: Sedimentology, v. 53, p. 789-823. 